\title{
Phytochemical, Antibacterial and Antioxidant Activities of Anthurium Hookerii leaves Extracts
}

\author{
Atmira Sariwati', Inayah Fitri ${ }^{2}$, Adi Setyo Purnomo³ ${ }^{3}$ Sri Fatmawati ${ }^{3 *}$ \\ 'Department of Tiongkok Traditional Medicine, Health Science Faculty, Institut Ilmu Kesehatan Bhakti Wiyata Kediri, Kediri, \\ Indonesia \\ ${ }^{2}$ Department of Biology, Faculty of Sciences, Technology and Analysis, Institut IImu Kesehatan Bhakti Wiyata Kediri, Kediri, \\ Indonesia \\ ${ }^{3}$ Department of Chemistry, Faculty of Science, Institut Teknologi Sepuluh Nopember, Surabaya, Indonesia
}

\section{ARTICLE INFO}

Article history:

Received July 18, 2018

Received in revised form October 18, 2018

Accepted March 1, 2019

\section{KEYWORDS:}

Antioxidant,

Antibacterial,

Anthurium hookerii,

DPPH assay,

Disc diffusion method

\begin{abstract}
Many plants of the family of Araceae possess significant benefit as medicinal plants. Anthurium hookerii is herbaceous genus of the family of Araceae. A. hookerii leaves were extracted with five dissimilarity solvents (methanol, water, ethyl acetate, $n$-hexane, and dichloromethane). The extracts were evaluated for their phytochemical, total phenolic contents and antibacterial potential. The presences of tannins and saponins were found in all crude extracts. The steroid was only found in dichloromethane extract, whereas flavonoid was obtained in methanol and water extracts. Besides; methanol, ethyl acetate, water, and $\boldsymbol{n}$-hexane extracts showed triterpenoid contents. Alkaloid presences in ethyl acetate, methanol, dichloromethane, and water extracts. The total phenol content was examined by Folin-Ciocalteu assay, which varied from $9.52-76.56 \mathrm{mg} / \mathrm{g}$ GAE. The highest total phenolic was found in methanol extract. Antioxidant activity was calculated based on diphenyl picryl hydrazyl radical scavenging ability that showed the scavenging activity with range $7.24-66.11 \%$, which the methanol extract has the excellent antioxidant potential $\left(\mathrm{IC}_{50} 232.90 \mu \mathrm{g} / \mathrm{ml}\right)$. Antibacterial activity of leaves extracts of $A$. hookerii was screened based on disc diffusion method. Water extract showed the wide spectrum antibacterial potential. Klebsiella sp., Bacillus subtilis, Pripioni agnes, and Strepticoccus mutans with maximum diameter of inhibition zone 10.30, $14.20,9.60$, and $15.10 \mathrm{~mm}$, respectively.
\end{abstract}

\section{Introduction}

For centuries, herbal medicines have been exploited in the enlargement of pharmaceutical yield, primary concern in worldwide health care (Graham et al. 2000). The adventages of herbal medicine is prospective of bioactivity. Those are generally collected as secondary metabolism in all plant tissues however their concentration range allow to the plant part, occasion, atmospheric condition, and appropriate growth phase (Maji et al. 2010).

The numerous of plants reacted to fluctuating atmospheric condition of environment by bringing forth antioxidant such as polyphenol. Raw extracts from plant have an essential antioxidants and bioactive compounds

\footnotetext{
* Corresponding Author

E-mail Address: fatma@chem.its.ac.id
}

are suitable to inhibit the oxidation processes caused of oxidizable substrates. The antioxidant absorbs and neutralizes reactive oxygen species such as hydrogen peroxide, superoxide, nitrit oxide (Djeridane et al. 2006; Kumar et al. 2013; Iloki-Assanga et al. 2015). Free radicals are continuously produced in the mitochondrial respiratory chain or due to exposure to environmental stress (atmospheric pollutants) and destructive of biomolecules such as DNA, lipid peroxidation and protein (Shui and Leong 2004; Ara and Nur 2009; Jebakumar et al. 2012), and it also can be implicated in many diseases like cancer, atherosclerosis, neurodegeneration and arthritis Parkinson's disease (Zetola et al. 2002; Makari et al. 2008; Jebakumar et al. 2012).

Another benefit of several medicinal plants is an antibacterial agent. Those are proven that have ability to inhibit the growth of pathogenic bacteria. Infectious diseases are still becoming health problem 
in development countries. According to Geyid et al. (2005), many infectious diseases such as cholera, diarrhea, lung disease and cure skin, can be treated by medicinal plants.

Within the recent years, infectious diseases have increased to a great extent and antibiotic resistance makes this condition more complicated to face and it needs several efforts to overcome this problem. The use of synthetic antioxidant is being restricted because of their toxicity and carcinogenic effects, so that herbal medicine more safety than synthetic medicine (Vongtou et al. 2005; Oluyemi et al. 2007; Saeed et al. 2012). Therefore, worldwide movements toward finding out chemical constituents from various parts of plant and the bioactivity studies of the novel drugs isolated. The family of Araceae has been proven as significant antibacterial and antioxidant agents.

Anthurium is herbaceous genus of the family of Araceae found through South America. Many species of Anthurium have been used as folk medicine to treat health disoders (Joly et al. 1987; Zamora-Martinez and de Pascual Pola 1992). The butanol extract of Anthurium versicolor leaves was measured for antioxidant potential by DPPH assay (Aquino et al. 2001). The flowers and leaves of Anthurium cerrocampanense have been used as an antiinflammantory agent (Segura et al. 1998). Anthurium acutangulum was used healing of cough disease (Duke 1986). Besides, Anthurium wagnerianum had stimulant activity (Di Carlo et al. 1964), while Anthurium adreanum also had potential against Bacillus, Staphylococcus, Escherichiu serratia, Pseudomonas, Proteus, Aerobacter, Klockera, Saccharomyces, Mycobacterium, Penicillium, Scopuloriopsis, and Fusarium (Donberger and Lich 1982). After studying several literatures, as yet there are no data related to the potential of $A$. hookerii as an antioxidant and antibacterial agents.

The purpose of this study was to screen different solvent extracts from $A$. hookerii leaves and tested the antioxidant activity, total phenolic contents, and antibacterial potential. The antioxidant activity was evaluated by DPPH scavenging, Folin- Ciocalteu assay was used to measure the total phenolic contents, phytochemical screening and antibacterial potential were evaluated by disk diffusion method as well.

\section{Materials and Methods}

\subsection{Chemicals}

All reagents and chemical including dichloromethane, methanol, $n$-hexane ethyl acetate, dimethyl sulfoxide
(DMSO), sulfuric acid $\left(\mathrm{H}_{2} \mathrm{SO}_{4}\right)$, hydrochloric acid $(\mathrm{HCl})$, Potassium iodide, iodine, glacial acetic acid, ferric chloride, chloroform, and nutrient agar (NA) and nutrient broth (NB), Folin-Ciocalteu, Mueller Hinton agar (MH agar) were purchased from Merck (Darmstadt, Germany) in high grade. DPPH (2,2-diphenyl-1 picrylhydrazyl) was purchased from Tokyo Chemical Industries (TCI, Tokyo, Japan). Gallic acid (Wako Pure Chemical Industries, Osaka, Japan).

\subsection{Bacteria Culture Conditions}

Cultures of Propioni agnes, Klebsiella sp.,Streptococcus mutans where obtained from the Collection of laboratory of Microbial Chemistry, Department of Chemistry, Institut Teknologi Sepuluh Nopember, Surabaya, Indonesia, B. subtilis NBRC 3009 (NITE Biological Resources Center, NBRC; Chiba, Japan), were cultivated on 9-cm diameter NA (Merck, Darmstadt, Germany) that had been incubated at $37^{\circ} \mathrm{C} .60 \mathrm{ml}$ of NB (Merck, Darmstadt, Germany) was prepared as medium to inoculate the colony and then pre-incubated at $37^{\circ} \mathrm{C}$ for $20 \mathrm{~h}$ with shaker at $180 \mathrm{rpm}$ (Wahyuni et al. 2016).

\subsection{Plant Material and Preparation of Sample}

Plant material was collected from home farm during January 2018 at Ngawi district of East Java, Indonesia. Fresh plant material of $A$. hookerii leaves were collected and washed with distilled water and cut into small pieces, dried overnight in an air dryer at $40^{\circ} \mathrm{C}$, ground to powder by using grinder.

\subsection{Extraction of $\boldsymbol{A}$. hookerii Leaves}

Dried powder of $A$. hookerii leaves samples (20 g) were placed in a $350 \mathrm{ml}$ Erlenmeyer flask, mixed with $200 \mathrm{ml}$ of solvents (water, methanol, ethyl acetate, dichloromethane, and $n$-hexane) separately and tightly wrapped with aluminum foil, and then extracted and shaken for 24 hour at $180 \mathrm{rpm}$ at $180 \mathrm{rpm}$, after which the suspensions was filtered throught Whatman No 1 filter paper. The supernatants were evaporated with rotatory evaporator maintained at $68^{\circ} \mathrm{C}$ for $n$-hexane extract, $100^{\circ} \mathrm{C}$ for water extract, $77^{\circ} \mathrm{C}$ for ethyl acetate extract, $40^{\circ} \mathrm{C}$ for dichloromethane extract, and $65^{\circ} \mathrm{C}$ for methanol extract to get dry extracts. Solvent free extracts were transferred to extract vials and store at $4^{\circ} \mathrm{C}$ for further used.

\subsection{Phytochemical Screening of $\boldsymbol{A}$. Hookerii}

Phytochemicals screening of various extracts A. hookerii were done qualitatively to detected the 
existence of tannins, flavonoids, alkaloids, saponins, and triterpenoids.

\subsubsection{Test for Alkaloids}

Test for alkaloids was done by Dragendroff's test: 2 $\mathrm{mg}$ of the A. hookerii extracts was added $5 \mathrm{ml}$ of distilled water. $2 \mathrm{M}$ hydrochloric acid $(\mathrm{HCl})$ was then added until an acid reaction occurs, which followed added 1 $\mathrm{ml}$ of Dragendroff's reagent. Formation of orange red precipitate expresses the existence of alkaloids (Joshi et al. 2013; Abdulahi et al. 2013; Iqbal et al. 2015).

\subsubsection{Test for Saponins}

A. hookerii leaves extracts $(0.5 \mathrm{~g})$ were flushtered with $10 \mathrm{ml}$ aquadest in glass tube. The formation of foaming which persist on heat up for $5 \mathrm{~min}$, expresses the existence of saponins (Banso and Adeyemo 2006; Iqbal et al. 2015).

\subsubsection{Test for Tannins}

A. hookerii leaves extracts ( $0.5 \mathrm{~g})$ were blended with $10 \mathrm{ml}$ aquadest and then separated to refine, additional with hardly any drops of $5 \%$ ferric chloride $\left(\mathrm{FeCl}_{3}\right)$. Formation of black or blue-green expresses the existence of tannins (Banso and Adeyemo 2006; Iqbal et al. 2015).

\subsubsection{Test for Steroids}

A. hookerii extracts $(0.5 \mathrm{~g})$ was boiled in $10 \mathrm{ml}$ chloroform $\left(\mathrm{CHCl}_{3}\right)$ and filtered, and then added $1 \mathrm{ml}$ of $\mathrm{CH}_{3} \mathrm{COOH}$ and few drops of sulfuric acid $37 \%\left(\mathrm{H}_{2} \mathrm{SO}_{4}\right)$ to the filtrate. Green ring indicates presence of steroid (Samejo et al. 2013).

\subsubsection{Test for Flavonoids}

A. hookerii leaves extracts $(0.5 \mathrm{mg})$ were dissolved in $0.5 \mathrm{ml}$ of its solvent (methanol), followed added a few drop of diluted sodium hydroxide $(\mathrm{NaOH})$ solution. Formation of yellow color and then additional with hardly any sulfuric acid made the colorless of exracts, expresses the existence of flavonoids (Alabri et al. 2014).

\subsubsection{Test for Triterpenoids}

Five-milliliter of $A$. hookerii leaves extracts were blended with $2 \mathrm{ml}$ of chloroform and few drops of $\mathrm{H}_{2} \mathrm{SO}_{4}$. Formation of blue/green ring expresses the existence of triterpenoids (Samejo et al. 2013).

\subsection{Total Phenolic Content}

One hundred-microliter of extract (20 mg A. hookerii leaves extracts were diluted into $3 \% \mathrm{HCL}$ and $60 \%$ methanol) additional with $2 \mathrm{ml}$ sodium carbonat. The mixture was allowed to stand for $3 \mathrm{~min}$, then FolinCiocalteu reagen was added. After standing $30 \mathrm{~min}$ measured the absorbance at $725 \mathrm{~nm}$. The standar curve was ploted by using Gallic acid 0.5, 1.0, 1.5, and 2.5 $\mathrm{mm}$. Total phenolic content precipate indicates of $\mathrm{mg}$ Gallic acid equivalent (GAE) per gram extract (Tsai et al. 2009).

\subsection{Antioxidant Potential (DPPH Free Radical Scavenging Ability)}

The reactive oxygen species scavenger of each extracts solution on DPPH radicals was resoluted as described earlier (Joly et al. 1987; Janet et al. 2015). $24 \mathrm{mg}$ DPPH were diluted with $100 \mathrm{ml}$ methanol for the stock solution and measured absorbance at 517 $\mathrm{nm}$. Thirty-three microliter of samples at different concentration $10-500 \mu \mathrm{g} / \mathrm{ml}$ were blended with $1 \mathrm{ml}$ DPPH stock solution then shaken and incubated in darkened for $20 \mathrm{~min}$ at room temperature. The control was only using DPPH stock solution. The scavenger ability was supposed focus on the percentage of DPPH radical scavenger as succeeding comparison:

$\underset{\text { Inhibition radical }}{\text { scavenging }(\%)}=\frac{\left[\begin{array}{c}\text { Control } \\ \text { absorbance }^{-}\end{array} \begin{array}{c}\text { Sample } \\ \text { absorbance }\end{array}\right]}{\text { Control absorbance }} \times 100$

The $\mathrm{IC}_{50}$ grade reflecting the concentration of sample needed to scavenge $50 \%$ of the DPPH free radical were estimated by achieving:

$$
\frac{\frac{1}{\mathrm{y}^{2}} \text { - weighted non - linier regression }}{\log (\text { Inhibitor concentration) }}
$$

vs arranged response model with a variable slope (Fitriana et al. 2016).

\subsection{Antibiotic Potential}

The antibacterial screening was accomplished by agar disc diffusion assay with determination of diameters of inhibition zones made by $A$. hookerii extract against various bacterial strains (Klebsiella sp. and P. agnes as Gram-negative bacteria, as well as B. subtilis and S. mutans as Gram-positive bacteria. Sterilized Mueller Hinton ( $\mathrm{MH}$ ) agar was poured into petri plates individually, and then inoculated with $100 \mu$ suspension of tested bacteria. Five-millimeter discs of Whatman No 1 filter paper were prepared and immersed in each of $1 \mathrm{ml}$ extracts solution (10 $\mathrm{mg}$ ) in DMSO (Alabri et al. 2014). The cultures were 
incubated at $37^{\circ} \mathrm{C}$ for 24 hours for maximal bacterial growth. Antibacterial potential was determined by calculating diameter $(\mathrm{mm})$ of inhibition zones using a zone reader. Commercial antibiotic disc of Chloramphenicol (10 $\mu \mathrm{g} /$ disc) was act as positive controls, while DMSO was act as a negative control.

\subsection{Statistical Analysis}

Values were the intermediate of three repetitions. Significant differences between or within groups during substrate transformation distinguished using Student $t$-test. Dissimilarity level of 5\% $(p<0.05)$ were through out to be statistically significant.

\section{Results}

Extraction yield mentions to the allotment of extracts, which aquired from powdered plant by using solvent extractions method for further isolation and application. Table 1 showed that among of five solvents, methanol produced the greatest extraction yields (1.92 g dried extract). However, this yield was not inevitably dissimilarity from the water extract (1.65 g dried extract). Both of methanol and water extracts were created to be inevitably different $(p<$ $0.05)$ compared with those dichloromethane $(0.76$ $\mathrm{g})$, ethyl acetate $(0.70 \mathrm{~g})$, and $n$-hexane extracts $(0.44$ g) dried extracts.

Phytochemical screening was shown in Table 2. Some secondary metabolites such as tannins and saponins were presented in all extracts. The presence of steroid was found only in dichloromethane extract. The presence of alkaloid was absent only in $n$-hexane extract. The presence of flavonoids was found in methanol and water extracts while triterpenoids content was found in ethyl acetate, methanol, $n$-hexane, and water extracts.

Total phenol of the A. hookerii was measured with Folin-Ciocalteu assay. Total phenolic compound grades were acquired from the standard curve method using Gallic acid ( $\left.\mathrm{y}=0.3636 \mathrm{x}-0.0077 ; \mathrm{r}^{2}=0.9988\right)$, where $\mathrm{y}$ is the absorbance and $\mathrm{x}$ is the concentration of Gallic acid solution $(\mu \mathrm{g} / \mathrm{ml})$ expressed $\mathrm{mg} / \mathrm{g}$ GAE. Total phenolic of $A$. hookerii extracts was shown in the Table 2. Methanol extract had the highest total phenolic content ( $76.56 \mathrm{mg} / \mathrm{g}$ GAE) among the various solvent of $A$. hookerii leaves extracts, closely followed by water extract ( $62.66 \mathrm{mg} / \mathrm{g}$ GAE), but significant different with ethyl acetate extract ( $26.85 \mathrm{mg} / \mathrm{g}$ GAE), closely followed by dichloromethane extract (26.85 $\mathrm{mg} / \mathrm{g}$ GAE) and the lowest was obtained by $n$-hexane extract ( $9.52 \mathrm{mg} / \mathrm{g} \mathrm{GAE})$.

Total antioxidant capacity of various solvent extracts of $A$. hookerii leaves were measured using the standard curve Gallic acid $\left(\mathrm{y}=34.80 \ln (\mathrm{x})-109.8 ; \mathrm{r}^{2}=0.970\right)$. The DPPH scavenging ability of methanol (66.11\%) was the highest than those of ethyl acetate (26.77\%), dichloromethane (18.18\%), water (15.22\%), and $n$-hexane (7.24\%) extracts. The positive control, Gallic acid, showed highest DPPH inhibition (97.80\%). The best antioxidant was obtained in methanol extract with $\mathrm{IC}_{50}$ values of DPPH radicals scavenging of $232.90 \mu \mathrm{g} / \mathrm{ml}$.

Table 1. Phytochemical screening of different extract of $A$. hookerii leaves

\begin{tabular}{lccccc}
\hline Phytochemical & \multicolumn{5}{c}{ Extracts solvent } \\
\cline { 2 - 6 } & Ethyl acetate & Methanol & Dichloromethane & $n$-hexane & Water \\
\hline Alkaloids & + & + & + & + & + \\
Tannins & + & - & + & + & + \\
Steroid & + & + & + & + & + \\
Saponins & - & + & - & + \\
Flavonoids & + & + & + & + \\
Triterpenoids & & & + & + \\
\hline
\end{tabular}

Table 2. Extractions yield, DPPH radical scavenging inhibitions and $\mathrm{IC}_{50}$ of $A$. Hookerii leaves extracts. Values are means with standard deviations $(\mathrm{n}=3)$

\begin{tabular}{lcccc}
\hline Solvents & Extraction yield $(\mathrm{g})$ & Total phenol $(\mathrm{mg} \mathrm{GAE} / \mathrm{g})$ & DPPH Inhibition $(\%)$ & $\mathrm{IC} \mathrm{C}_{50}(\mu \mathrm{g} / \mathrm{ml})$ \\
\hline Water & 1.40 & $62.66 \pm 0.51^{\mathrm{a}}$ & $15.22 \pm 0.03^{\mathrm{a}}$ & - \\
Methanol & 1.64 & $76.56 \pm 0.45^{\mathrm{b}}$ & $66.11 \pm 0.02^{\mathrm{b}}$ & 232.90 \\
Ethyl acetate & 1.02 & $26.85 \pm 0.12^{\mathrm{c}}$ & $26.77^{\mathrm{a}} \pm .01^{\mathrm{c}}$ & - \\
Dicloromethane & 1.12 & $26.08 \pm 0.14^{\mathrm{d}}$ & $18.18 \pm 0.03^{\mathrm{d}}$ & - \\
n-hexane & 0.66 & $9.52 \pm 0.19^{\mathrm{e}}$ & $7.24 \pm 0.01^{\mathrm{e}}$ & - \\
\hline
\end{tabular}

(-) Not measured, DPPH inhibition (\%) $<50 \%$. Data are mean \pm standard deviation $(n=3)$. Data followed by the same minor letter on each row are significantly different $(p<0.05)$ 
Antibacterial activity of $A$. hookerii leaves extracts against 4 pathogenic bacteria was shown in Table 3 . Water extract showed the excellent activities against Klebsiella sp. (10.30 mm) and B. subtilis $(14.20 \mathrm{~mm})$, which inhibition zone greater than the positive control (chloramphenicol). The inhibition zone of water extract was obtained against $P$. agnes $(9.6 \mathrm{~mm})$ and $S$. mutans $(15.10 \mathrm{~mm})$. Methanol extract showed activity against Klebsiella sp. with inhibition zones of $9.10 \mathrm{~mm}$. However, dichloromethane, ethyl acetate, and $n$-hexane extracts showed the low antibacterial activities against four bacteria, because they could not yet surpass the positive control.

\section{Discussion}

\subsection{Extraction Yield}

Yield product of extraction by using dissimilarity solvent resulted dissimilarity percentage yield (Salamah et al. 2008). Polar solvents extracted significantly greater yield than the nonpolar counterpart. The effectiveness of methanol extracts describe the intermediate polarity, which admit it to solvate low molecular weight organic composition possessing proton table utilitarian groups (e.g. $\mathrm{COOH}, \mathrm{OH}$ ) (Nguyen et al. 2015). The greatest extraction yield was acquired by methanol solvent, which may be as in owing to the greatest solubility of carbohydrates and protein in methanol (Zielinski and Kozlowska 2000; Do et al. 2014).

\subsection{Phytochemical Screening}

Phytochemical screening of different extracts of $A$. hookerii showed varied results, which the attendence major of phytochemical such as saponins and tannins. Tannins and its descendents are phenol constituents deliberated to be main antioxidants or free radical scavenger (Barile et al. 2007; Ayoola et al. 2008; Varahalarao and Kaladhar 2012; Sekar et al. 2012; Alabri et al. 2014). Saponins are like wise bioactive constituents that complicated in plant defense system because of their antibacterial and antifungus potential (Barile et al. 2007; Ayoola et al. 2008; Alabri et al. 2014) and as antioxidant as well as anti-inflammatory agents (Najafi et al. 2010; Samejo et al. 2013). However, ethyl acetate, dichloromethane, water, and methanol extracts also were detected other bioactive compounds, alkaloid. Numerous of alkaloids descendent from herbal medicines showed bioactive compounds such as antimicrobial (Benbott et al. 2012; Iqbal et al. 2015). The attendence of flavonoid was obtained in methanol water and methanol. Flavonoids are antioxidant compound as a free radical scavenger (Nurjanah et al. 2015). Besides, steroid was only found in dichloromethane extract. Steroids were announced to have antibiotic (Yadav and Agarwala 2011; Samejo et al. 2013). Methanol, water, $n$-hexane, ethyl acetate extracts showed triterpenoid contents. Triterpenoid have been demonstrated to have antibiotic properties (Najafi et al. 2010; Samejo et al. 2013). The previous reported that $n-\mathrm{BuOH}$ extract from leaves of $A$. versicolor revealed presence of phenolic compounds (including flavonoid and phenyl propanoid derivatives) (Aquino et al. 2001). Aquaeous, chloroform and ethanol extracts from leaves of $A$. adreanum revealed presence of tannin (Shazhni et al. 2016).

\subsection{Total Phenol Contents}

Among five extracts of $A$. hookerii, methanol extract presented the greatest total of phenol $(76.56 \mathrm{mg} / \mathrm{g} \mathrm{GAE})$, followed by water $(62.66)>$ ethyl acetate $(26.85 \mathrm{mg} / \mathrm{g}$ $\mathrm{GAE})>$ dichloromethane $(26.08 \mathrm{mg} / \mathrm{g} \mathrm{GAE})>n$-hexane (9.52 $\mathrm{mg} / \mathrm{g}$ GAE). Amount of total phenolic in the dissimilarity of extracts is affected by polarity solvent which carried out for extraction (Alothman et al. 2009; Sulaiman et al. 2011; Iloki-Assana et al. 2015). Solvent polarity plays the main of accumulating total phenol content (Naczk and Shahidi 2006; Medini et al. 2014). These phenolic compounds may possess more phenol

Table 3. Antibacterial activity of $A$. hookerii leaves extracts

\begin{tabular}{lcccc}
\hline \multirow{2}{*}{ Solvents } & \multicolumn{3}{c}{ Diameter of inhibition zone $(\mathrm{mm})$ bacteria } \\
\cline { 2 - 5 } & Klebsiella sp. & B. subtilis & Propioni agnes & Strepticoccus mutans \\
\hline Water & $10.30 \pm 1.21^{\mathrm{aA}}$ & $14.20 \pm 0.30^{\mathrm{aB}}$ & $9.60 \pm 0.50^{\mathrm{aA}}$ & $15.10 \pm 0.70^{\mathrm{aB}}$ \\
Methanol & $9.10 \pm 0.61^{\mathrm{AA}}$ & $6.00 \pm 0.10^{\mathrm{bB}}$ & $6.60 \pm 0.60^{\mathrm{bB}}$ & $7.50 \pm 0.50^{\mathrm{bC}}$ \\
Ethyl acetate & $7.40 \pm 0.10^{\mathrm{bA}}$ & $6.20 \pm 1.61^{\mathrm{bA}}$ & $6.80 \pm 0.20^{\mathrm{bA}}$ & $7.10 \pm 0.80^{\mathrm{bA}}$ \\
Dicloromethane & $6.40 \pm 1.31^{\mathrm{bA}}$ & $6.50 \pm 0.61^{\mathrm{bA}}$ & $6.70 \pm 0.10^{\mathrm{bA}}$ & $6.60 \pm 0.20^{\mathrm{cA}}$ \\
$n$-Hexane & $6.00 \pm 0.20^{\mathrm{bA}}$ & $6.00 \pm 0.40^{\mathrm{bB}}$ & $6.00 \pm 0.80^{\mathrm{bB}}$ & $6.00 \pm 0.61^{\mathrm{cB}}$ \\
Chloramfenicol & $6.00 \pm 0.41^{\mathrm{bA}}$ & $9.40 \pm 0.30^{\mathrm{cB}}$ & $22.10 \pm 0.51^{\mathrm{cC}}$ & $42.00 \pm 1.51^{\mathrm{dD}}$
\end{tabular}

(positive control)

Data are mean \pm standard deviation $(n=3)$. Data followed by the same minor letter on each row or by the same capital letter on each column are significantly different $(p<0.05)$ 
in the methanol extract. Chemical group of compounds in the methanol extract implied in this total phenol compound. Phenolic, which are aromatic rings that have one or more acidic phenolic hydroxyl group, are further classified into hydroxycinnamic acids, flavonoids, anthocyanins, and tannins (Unal et al. 2014). The tannins contents are with more half of the polyphenol contents, so the capacity reductive of the $\mathrm{Fe}(\mathrm{III})$ in $\mathrm{Fe}(\mathrm{II})$ is in the order of the tannin contribution on the polyphenols content (Bangou et al. 2012). This result similar with previous report that methanol have been confirmed as suitable solvent for extraction of total phenolic contents (Siddhuraju and Becker 2003; Iloki-Assanga et al. 2015). $n$-hexane was the lowest total phenolic content that may be as in owing to the non-phenolic compounds like terpene and carbohydrate than in order extract. This result was different significant with previous work that confirm the highest total phenol content of crude $n$-BuOH extract of $A$. versicolor was obtained 190.6 $\mu \mathrm{g} / \mathrm{mg}$ (Aquino et al. 2001). The higher total phenol content in plant could have relation with plant stress with the possibility of the presence of polyamines as stress indicators (Unal et al. 2014).

\subsection{Antioxidant Potential (DPPH Scavenger and $\left.\mathrm{IC}_{50}\right)$}

The reactive oxygen species scavenger of the $A$. hookerii leaves extracts were tested through DPPH method. The fundamental of DPPH assay is that the formation of stable free radical that caused by antioxidant agents react with DPPH free radical and its followed by the loss of violet color. This phenomenon indicates the sample contain antioxidant agent (Hossain et al. 2014). The highest DPPH scavenging ability was obtained by methanol extract (66.11\%) and the positive control, Gallic acid, showed higher DPPH inhibition (97.80\%). The different extracts obtained difference in the secondary metabolite constituent as reflected in the result of antioxidant potential (Janet et al. 2015). The high antioxidant potential of methanol extract possibly caused by the presence tannin, flavonoid, and saponin (Table 1). Antioxidant compound of flavonoids are contributed to transfer an electron or to donate hydrogen atom to the free radical stability and to chelated metal (Redha 2010). Saponin compounds are radical scavenger by forming hydrogen peroxide as transitional that donating hydrogen to a proton DPPH free radical that finished radical chain reactions (Xiong et al. 2010; Nurjanah et al. 2015). Tannins have abilities to catch free radicals. These compounds are more easy to release electron and hydrogen atom and metal chelation activities, because there were hydroxyl group and conjugated double bonds that admit to remove electron (Nurjanah et al. 2015). n-hexane extracts demands more concentration to accomplish free radical scavenger caused the property of the nonpolar solvent including essential oils, fat, and wax, so that does not have antioxidant activity (Suratmo 2009; Nurjanah et al. 2015).

The half-inhibition concentration $\left(\mathrm{IC}_{50}\right)$ is reciprocally correlated which its antioxidant potential, it is expresses the concentration of antioxidant required to decrease the DPPH concentration by $50 \%$, which is obtain by plotting from linear regression analysis. A descend $\mathrm{IC}_{50}$ expresses an excellent antioxidant potential (Liu et al. 2009; Do et al. 2014). In this study, methanol extract showed the best antioxidant with $\mathrm{IC}_{50} 232.90 \mu \mathrm{g} / \mathrm{ml}$. These result are consistent with bioactive compounds of phenol detected in the methanol extract include flavonoids, tannins, and saponins, which proved that the methanol extract was the greater total phenolic content. Generally, most of antioxidant compounds are phenolic that have hydroxyl group interchanged in the ortho position to the - $\mathrm{OH}$ and -OR (Andayani et al. 2008; Nurjanah et al. 2015). Methanol extract of $A$. hookerii is classified as a weak antioxidant because IC $_{50}$ values more than 200 ppm (Molyneux 2004; Nurjanah et al. 2015). This result similar with chloroform extract of Alocasia fornicate leaves $(248.85 \mu \mathrm{g} / \mathrm{ml})$ and $n$-hexane of extract Alocosia marcrorbiza leaves $(245.17 \mu \mathrm{g} / \mathrm{ml})$ belong to the family Araceae (Mandal et al. 2010). $n$-BuOH extract from the leaves of $A$. versicolor has $\mathrm{EC}_{50} 142.6 \mu \mathrm{g} / \mathrm{ml}$ (Aquino et al. 2001).

\subsection{Antibacterial Potential}

The in vitro antibiotic potential of the five $A$. hookerii leaves crude extract against four bacteria was qualitative method by the existence or thereness of inhibition zones. Extracts are active if it induces an inhibition zone superior at $3 \mathrm{~mm}$ around the disc (Schulz et al. 1995; Bangou et al. 2012). Taking account of this consideration, all extracts were active on the following species S. mutans, B. subtilis, Klebsiella sp., and P. agnes. The maximum inhibition zones were $15.10,14.20,10.30$, and $9.60 \mathrm{~mm}$ in S. mutans, B. subtilis, Klebsiella sp., and $P$. agnes, respectively, which obtained from water extract. Water extract was the most effective against Klebsiella sp. and $B$. subtilis, because the inhibition zone was higher than positive control. While trying to understand, the reason of this strong inhibition of water extract 
because bioactive compound of plant that produced by secondary metabolism are utilized for protect from fluctuating environment condition, such as flavonoid, alkaloid, triterpenoid, and saponin that produced wide spectrum antibiotic agents (Mansour et al. 2010; Tiwari et al. 2014). Alkaloids have been demonstrated effective compounds from herbal medicine that have bioactive compound such as antimicrobial (Benbott et al. 2012; Iqbal et al. 2015), which had bioactivity rivals' Grampositive bacteria (Omar et al. 1992; Iqbal et al. 2015). Flavonoids capable to form extracellular complexes with proteins that dissolves easily likewise with bacterial cells walls, hydrophobic flavonoids mighty bacterial membranes damage (Clements et al. 2002; Tamil et al. 2011). Triterpenoids are known to weaken the membranous tissue, which results in dissolving cell wall organism (Rao et al. 2003; Okwu and Okwu 2004; Verughese and Tripathi 2013). Play roles of saponin as antibacterial agents by exposure of protein membrans and extracellular enzymes (Tamil et al. 2011). In this study, strong inhibition can be related to the enough content of polyphenolic compounds. Also the phenolic compounds in particular the tannins are suitable for precipitation during the reactions of oxidation and that could be factor of toxicity with respect to the microorganism (Bakasso et al. 2008; Bangou et al. 2012). The best antibacteria activity with highest inhibition zone of water extract was obtained on the Gram-positive bacteria (S. mutans), which are very rich in peptidoglycane (50-80\% of the lining); consist of several layers of peptidoglycan an having reticulation (Bangou et al. 2012). One of the peptidoglycanes roles is to ensure the rigidity and the solidity lining of the bacterial as well as the protection of the cytoplasmic membrane against osmotic lysis (Bangou et al. 2012). Besides, methanol extract had antibacteria activity against Klebsiella sp. This result different significant with previous reported, methanol extract of Anthurium sp. leaves had not ability against bacteria (Bonjar et al. 2004). Acetone, chloroform, and ethanol extracts from leaves of $A$. adreanum showed inhibition potential against S. aureus, E. coli and Bacillus careus (Shazni et al. 2016).

\subsection{The Correlation of Total Phenol, Antioxidant, and Antibacterial Potential}

The reciprocally of the total phenol contents with antioxidant potential $A$. hookerii was evaluated. There was correlation between total phenol content and antioxidant potential as well as the $\mathrm{IC}_{50}$. A remarkable and linear correlated between the antioxidant potential and total phenol content of methanol extract, thus expressing that total phenol contents are main contributors to antioxidant potential (Maizura et al. 2011), total phenol is primary due to redox abilities that could to form free radical stable (Jimoh and Afolayan 2011; Iloki-Assanga et al. 2015). This result not difference significant with the previous report which evaluated the correlation between antioxidant potential and total phenol content of 133 species of herbal medicines of Indiana (Surveswaran et al. 2007; Bangou et al. 2012). Hardiana et al. (2012). There was correlation of amount total phenol content with antibacterial potential, it was caused biological compound of total phenol in water extract including alkaloids, tannins, saponins, triterpenoids, and flavonoid. The excellent of antimicrobial activities caused by excistence of alkaloid, tannin, terpenoids (Cowan 1999).

\section{Acknowledgements}

This work was promoted by appropiation from the Research Project "Penelitian Dosen Pemula" from Directorate General of Strengthening Research and Development, Ministry of Research, Technology and Higher Education, Indonesia.

\section{References}

Abdulahi SI et al. 2013. Evaluation of phytochemical screening and analgesic activity of aqueous extract of the leaves of Microtrichia perotitii dc (Astraceae) in mice using hotplate method. Med Plant Res 3:37-43.

Andayani $\mathrm{R}$ et al. 2008. Penentuan aktivitas antioxidant, kadar fenolat total dan likopen pada tomat (Solanumlycopersium L.). Jurnal Sains dan Teknologi Farmasi 3:1-9.

Alabri TH et al. 2014. Comparative study of phytochemical screening, antioxidant and antimicrobial capacities of fresh and dry leaves crude plant extracts of Datura metel L. Journal of King Saud University-science 26:237-243.

Alothman M et al. 2009. Antioxidant capacity and phenolic content of selected tropical fruits from malaysia extracted with different solvents. Food Chem 115:785788.

Aquino R et al. 2001. Phenolic constituents and antioxidant activity of an extract of Anthurium versicolor leaves. J Nat Prod 64:1019-1023.

Ara N, Nur H. 2009. In vitro antioxidant activity of methanolic leaves and flowers extracts of Lippia alba. Research journal of medicine and medical sciences 4:107-110.

Ayoola GA et al. 2008. Phytochemical screening and antioxidant activities of some selected medicinal plant used for malaria therapy in Southwestern Nigeria. Trop J Pharm Res 7:1019-1024. 
Banso A, Adeyamo S. 2006. Phytochemical screening and antimalarial assessment of Abutilon mauritianum, Bacopa monnifera and Datura stramonium. Biokemistri 18:39-44.

Barile E et al. 2007. Phytochemical screening and antimicrobial assessment of Abutilon mauritianum, Bacopa monnifera and Datura stramonium. Phytochemistry 68:596-603.

Bakasso SA et al. 2008. Polyphenol content and antioxidant activities of five Indigofera species (Fabaceae) from Burkina Faso Park. J Biol Sci 11:1429-1435.

Bangou MJ et al. 2012. Antioxidant and antibacterial activities of five Verbaneceae species from Burkina Faso. Current Research Journal of Biologica Sciences 4:665-672.

Benbott A et al. 2012. Assesment of the antibacterial activity of crude alkaloids extracted from seed and roots and plant Peganumharmala L. J Nat Prod Plant Resour 2:568-573.

Bonjar GHS et al. 2004. Antibacterial and antifungal survey in plants used in indigenous herbal-medicine of South east Regions of Iran. Journal of Biological Sciences 4:405-412.

Cowan MM. 1999. Plant products as antimicrobial agents. Clinical Microbiology Review 12:564-582.

Clements JM et al. 2002. Antibacterial activities and characterization of novel inhibitors of LpxC. $J$ Antimicrbial Agents and Chemotherapy 46:1793-1799.

Di Carlo FJ et al. 1964. Rheticulo endothelial system stimulants of botanical origin. Journal of the Reticulo endothelial Society 1:224-232.

Djeridane A et al. 2006. Antioxidant activity of some Algerian medicinal plants extracts containing phenolcompounds. Food Chem 97:654-660.

Duke JA. 1986. Isthmian Ethnobotanical Dictionary. $3^{\text {rd }}$ ed. Jodphar: Scientific Publications.

Do QD et al. 2014. Effect of extraction solvent on total phenol content, total flavonoid content, and antioxidant activity of Limnophila aromatica. Journal of Food and drug Analysis 22:296-302.

Donberger K, Lich H. 1982. Screening nach antimicrobiell sowie potentiell cancerostatisch wirksamen pflanzeninhaltsstoffen. Pharmazie 37:215-221.

Fitriana WD et al. 2016. Antioxidant activity of Moringa oleifera extracta. Indonesia J Chem 16:297-301.

Geyid A et al. 2005. Screening of some medicinal plants of ethiopia for their anti-microbial properties and chemical profiles. Journal of Ethnopharmacology 97:421-427.

Graham JG et al. 2000. Plant used against cancer-an extention of the work of Jonathan Hartwell. J Ethnopharmacol 7:347-377.

Hardiana $\mathrm{R}$ et al. 2012. Aktivitas antioksidan senyawa golongan fenol dari beberapa jenis tumbuhan famili Malvaceae. JKK 1:8-13.

Hossain MA et al. 2014. Comparative study of total phenolics, flavonoids contents and evaluation of antioxidant and antimicrobial activities of different polarities fruits crude extracts of Datura metel L. Asian Pasific Journal of Tropical Disease 4:378-383.

Iqbal E et al. 2015. Phytochemical screening, total phenolics and antioxidant activities of bark and leaf extracts of Goniothalamus velutimus (Airy Shaw) from Brunei Darussalam. Journal of King Saud University-Science 27:224-232.
Iloki-Assanga SB et al. 2015. Solvent effect on phytochemical constituent profiles and antioxidant activities, using four different extraction formulation for analysis of Bucida buceras L. and Phoradendron californicum. BMC Res Notes 8:396-410.

Janet JR et al. 2015. Free radical scavenging activity and bioactive secondary metabolites from various extracts of Glinusoppositifolius (L) Aug. DC. (Molluginaceae) roots, stem, and leaves. Asia Pac J Trop Dis 5:711-715.

Jebakumar AZ et al. 2012. Natural antioxidant and in vitro metods for antioxidant activity. International Journal of Pharmacoloy Research 2:46-55.

Jimoh FO, Afolayan AAAAJ. 2011. Comparison of the nutritive value, antioxidant and antibacterial activities of Sonchus asper and Sonchus oleraceus. Records of Natural Products 5:29-42.

Joly LG et al. 1987. Ethnobotanical inventory of medicinal plants used by the Guaymi Indians in Western Panama. Part I. J Ethnopharmacol 20:145-171.

Joshi A et al. 2013. Phytochemical investigation of roots of Grewla microcos Linn. J Chem Pharm Res 5:80-87.

Kumar S et al. 2013. Antioxidant mediated protective effect of Parthenium hysterophorush against oxidative damage using in vitro. BMB Complement Altern Med 13:120-128.

Liu SC et al. 2009. Antioxidant properties of various solvent extracts from lychee (Litchi chinesis sonn) flowers. Food Chem 126:1122-1126

Maji S et al. 2010. In vitro antimicrobial potentialities of different solvent extracts of Ethnomedicinal plants against clinically isolated human pathogens. J Phytol 2:57-64

Mandal P et al. 2010. Antioxidant activity in the extract of two edible aroids. Indian Journal of Pharmaceutical Sciences 72:105-108.

Mansour S et al. 2010. Antibacterial activity of hydroalchlolohic extract Callistemon citrinus and Albiza lebbeck. American Journal of Apllied Science 7:13-16.

Medini F et al. 2014. Total phenolic, flavonoid and tannin contents and antioxidant and antimicrobial activitie of organic extracts of shoots of the plant Limonium delicatulum. Journal of Taibah University for Science 8:216-224.

Maizura M et al. 2011. Total phenolic content and antioxidant activity of kesum (Polygonum minus), ginger (Zingiber officinale) and tumeric (Curcuma longa) extract. International Food Research Journal 18:526-531.

Makari HK et al. 2008. In vitro antioxidant activity of the hexane and methanolic extracts of Cordial wallichi and Celatrus paniculata. The Internet J Aesthetic and Antiaging Medicine 1:1-10.

Molyneux P. 2004. The use of the stable free radical diphenylpicrylhydrazyl (DPPH) for estimating antioxidant activity. Journal Science of Technology 26:211-219.

Najafi S et al. 2010. Phytochemical screening and antibacterial activity of Citrulluscolocynthis (Linn) Sahrad against Staphylococcus aureus. J Med Plants Res 4:2321-2325.

Naczk M, Shahidi F. 2006. Phenolic in cereals, fruits and vegetables: occurance, extraction and analysis. $J$ Pharm Biomed Anal 41:1523-1542. 
Nguyen VT et al. 2015. Phytochemicals and antioxidant capacity of Xao tam phan (Paramignyatrimera) rot as affected by various solvents and extractions methods. Industrial Crops and Products 67:192-200.

Nurjanah N et al. 2015. Bioactive compounds and antioxidant activity of Lindur stem bark (Bruguiera gymnorrhiza). International Journal of Plant Science and Ecology 1:182-189.

Omar S et al. 1992. Penanthrene lactams from Goniothalamus velutinus. Phytochem 31:4395-4397.

Okwu DE, Okwu ME. 2004. Chemical composition of Spondias mombin linn. Plant part. J Sustain Agric Environ 6:140-147.

Oluyemi KA et al. 2007. Toxic effect of methanolic extract of Aspilia africana leaf on the estrous cycle and uterine tissues of wistar rats. Int J Morphol 25:609-614.

Rao CV et al. 2003. Analgesic, antiinflamatory and antiulcerogenic activity of unripe fruits Aegle marmelos. Acta Pharmacetica Turcica 45:85-91.

Redha A. 2010. Falvonoid: struktur, sifat antioksidatif dan peranannya dan perannya dalam sistem biologis. Jurnal Belian 9:196-202.

Samejo MQ et al. 2013. Phytochemical screening of Tamarix diocia roxb. ex roch.J Pharm Res 7:181-183.

Saeed $\mathrm{N}$ et al. 2012. Antioxidant activity, total phenolic and total flavonoid contents of whole plant extracts Torilis leptophylla L. BMC Complementary and Alternative Medicine 12:221-233.

Schulz BJ et al. 1995. Biological active secondary metabolites of endophetic Pezcula species. Mucol Res 99:100710015.

Sekar D et al. 2012. Screening of Phyllanthusamarus, Acalyphaindica and Datura metel for it s antimicrobial activity against selected pathogen. International Journal of Phermaceutical and Biological Archives 3:1231-1235.

Surveswaran S et al. 2007. Systematic evluation of natural phenolic antioxidant from 133 Indian medicinal plants. Food Chem 102:938-953.

Salamah E et al. 2008. Penapisan awal komponen bioaktif dari Kijing Taiwan (Anadonta woodiana lea) sebagai senyawa antioksidan. Buletin Teknologi Hasil Perikanan 11:119-132.

Siddhuraju P, Becker K. 2003. Antioxidant properties of various extracts of total phenolic constituent from three different agroclimatic origins of drumstik tree (Moringa oleifera lam) leaves. J Agric Food Chem 51:2144-2155.

Sulaiman S et al. 2011. Effect of solvent in extracting polyphenols and antioxidant of selected raw vegetables. Food comp anal 24:506-515.

Suratmo. 2009. Potensi ekstrak daun sirih merah (Piper crocatum) sebagai antioksidan. Journal Penelitian 205:1-5.

Shazhni JRA et al. 2016. Phytochemical screening and in vitro antimicrobial activity of ornamental plant Anthurium andraeanum. Journal of pharmaceutical Sciences and Rsesearch 8:668-670.
Shui GH, Leong LP. 2004. Analysis of polyphenolic antioxidant in star fruit using liquid chromatography and mass spectrometry. J Chromatogr 1022:67-75.

Segura L et al. 1998. Anti-inflammatory activity of Anthurium cerrocampanense croat in rats and mice. $J$ Enthopharmacol 61:243-248.

Tamil SA et al. 2011. Leaf and seed extracts of Bixa orellana L. exert antimicrobial activity against bacterial pathogens. Journal of Applied Pharmaceutical Science $1: 116-120$.

Tiwari U et al. 2014. Evaluation of antioxidant and antibacterial activities of methanolic leaf extract of Calistemon viminalis. International Journal of Pharmaceutical Sciences and Business Management 2:1-12.

Tsai SY et al. 2009. Flavour components and antioxidant properties of several cultivated mushrooms. Food Chemistry 113:578-584.

Unal $\mathrm{K}$ et al. 2014. Polyphenol content and antioxidant capacity in organically and conventionally grown vegetables. Journal of Coastal Life Medicine 2:864-871.

Varahalarao V, Kaladhar DSVGK. 2012. Antimicrobial study of plant extracts of Datura matel L against some important disease causing pathogen. Asia Pac J Trop Dis 2:94-97.

Varughese B, Tripathi J. 2013. Phytochemical evaluation of different solvent extracts of Aegle marmelos fruit at different stages of its ripening. Advances in Life Science and Technology 8:8-12.

Vungtou HO et al. 2005. Central inhibitory effects of the methanol extract of Neoroutanenia mitis root in rats and mice. J Pharm Biol 43:113-120.

Wahyuni S et al. 2016. Purification and characterization of thermostable chitinase from Bacillus SW41 for chitin oligomer production. Asian Journal of Chemistry 28:2731-2736.

Xiong Y et al. 2010. Preparation and biological activity saponin Ophiogon japonicas. African Jornal of Farmacy and Pharmacology 6:1964-1970.

Yadav RNS, Agarwala M. 2011. Phytochemical analysis of some medicinal plants. J Phyto L 3:10-14.

Zamora-Martínez MC, de Pascual Pola CN. 1992. Medicinal plants used in some rural populations of oaxaca, puebla and veracruz, mexico. Journal of Ethnopharmacology 35:229-257.

Zetola M et al. 2002. CNs activities of liquid and spray-dried extracts from Lippia alba verbenaceae (Brazihian false Melisa). J ethnopharmacology 82:207-215.

Zielinski H, Kozlowska H. 2000. Antioxidant activity and total phenolic in selected cereal grains and their different morphological fractions. J Agric Food Chem 48:2008-2016. 